\title{
Erratum to: Collaborative Consumption 2.0: An Alternative to Fast Fashion Consumption
}

\author{
Jochen Strähle and Carina Erhardt
}

\section{Erratum to:}

Chapter 8 in: J. Strähle (ed.), Green Fashion Retail, Springer Series in Fashion Business, DOI 10.1007/978-981-10-2440-5_8

In the original version of Chapter 8, the second author's name was inadvertently published with a typo error as "Carina Erhard" and it should read as "Carina Erhardt". The erratum chapter and the book have been updated with the changes.

The updated original online version for this chapter can be found at 10.1007/978-981-10-2440-5_8

J. Strähle $(\bowtie) \cdot$ C. Erhardt

School of Textiles and Design, Reutlingen University, Reutlingen, Germany

e-mail: jochen.straehle@ reutlingen-university.de

C. Erhardt

e-mail: carinaerhardt@gmx.de 